\title{
Status of Knowledge Management Practices in Pakistani Universities
}

Rehmat Shah $^{1}$, Syed Asad Abbas Rizvi ${ }^{2}$, Nabi Bux Jumani ${ }^{3}$

\begin{abstract}
Knowledge Management (KM) is the process of knowledge creation, knowledge acquisition, knowledge dissemination, knowledge storage and knowledge reapplication. It is considered as one of the most important area of research in the era of globalization. Knowledge management practices are one of the important areas of knowledge management. The objectives of this study were to explore the perceptions of $\mathrm{PhD}$ approved supervisors about six factors of knowledge management. The study was quantitative in nature and cross sectional survey was used as method of the study. The population of study was all 4636 approved $\mathrm{PhDs}$ research supervisors of all public and private sector universities in Pakistan. By multi-stage sampling techniques $465 \mathrm{PhD}$ approved supervisor were selected as sample. Seven major areas which were definition, plan, strategies, framework, unit, budgets, and coordination point of knowledge management in Pakistani universities were examined. Study concluded that there is absence of definitions, plan, strategies, framework, unit, budgets, and coordination point of knowledge management for practices and its implementation in universities of Pakistan. The results recommended that there may be provided knowledge management practices definitions in universities of Pakistan. Higher Education Commission and universities may be equipped with knowledge management unit, framework, coordination point and budgets for implementation.

Keywords: Knowledge, Knowledge Management, Higher Education, Framework

\section{Introduction}

Knowledge Management is aroused as emerging and new phenomena of $21^{\text {st }}$ century. All over the world, knowledge management practices are considered as an interactive and favorite area of research and practices for researchers. There are two broad types of knowledge i.e. tacit knowledge and explicit knowledge which are considered as roots of knowledge. Tactic knowledge is referred as that knowledge which resides in human mind. It cannot be articulated easily. Explicit
\end{abstract}

\footnotetext{
${ }^{1} \mathrm{PhD}$ Scholar, Department of Education, IIUI Email: rehmatshah786@gmail.com ${ }^{2}$ Assistant Professor, Department of Education, IIUI Email: drasad.rizvi@iiu.edu.pk

${ }^{3}$ Professor, Department of Education, IIUI Email: nb.jumani@iiu.edu.pk
} 
knowledge means open and database knowledge. It is easy to access and can be effortlessly articulated by searchers. According to Nawaz \& Gomes (2014), tacit knowledge is based on the idea that we know more than we can present, and explicit knowledge is carefully arranged and systematically stored in database.

Knowledge management as filed and subject is accepted all over the educational and academic world. Universities and higher education institutions are the source of knowledge creation, knowledge dissemination, knowledge storage, knowledge accusations and knowledge application. Knowledge management practices in higher education institutions are acknowledged by every country. Davenport (1998) clarified knowledge management as a process for capturing of knowledge, spreading of knowledge and effectively use of knowledge for any type of organizational development and growth. According to Serenko (2013), Knowledge Management has already reached the level of a scientific discipline. Petrides \& Nodine (2003) opined that Knowledge management practices as notions were accepted in the field of education due to achieved competitive advantages for face pressure of globalization and knowledge economy. In the field of research, knowledge management is new and inevitable. Knowledge management practices has been attracted by researchers but knowledge management practices research has been found very limited in numbers globally in general and in the South East Asian region in specific ( Sohail \& Daud, 2009). Pakistan is also located in South Asia region of the world and has limited theoretical levels of knowledge management practices in universities.

Rowley (2000) suggested that knowledge management activities in universities are important for development and must be ensured for recognition and used as foundation. Mikulecky and Saeed (2009) articulated and considered the importance of knowledge management for academic sector of Pakistan. The authors further explained key areas of higher education which can be directly improved by knowledge management practices. The author further proposed that universities must respond to their changing role in a knowledge-based society and managing their explicit created new knowledge assets.

\subsection{Statement of Problem}

Knowledge management is not only the need of society but also very crucial for universities. Knowledge management practices and strategies can help stakeholders of universities for improving organizational and educational achievements. Therefore, researcher was attracted to explore the perceptions of $\mathrm{PhD}$ approved supervisors about knowledge management practices in universities. The problem investigated the perceptions of $\mathrm{PhD}$ approved supervisor about knowledge management practices in universities. 


\subsection{Objectives of Study}

Objectives of the study were:-

1. To find out the perceptions of PhD approved faculty about definition of knowledge management as given by the universities.

2. To find out the implementation plan for knowledge management in universities.

3. To explore the perceptions of Ph.D approved supervisors regarding availability of primary coordination points for knowledge management practices in universities.

4. To investigate the availability of knowledge management framework and knowledge management units in universities

5. To find out the perceptions of Ph.D approved supervisors about availability of separate budget for knowledge management practices in universities of Pakistan.

\section{Literature Review}

The term and concept of knowledge management was aroused in 1990s. Knowledge management is a set of practices and procedure that helps to use and sharing of information in decision making (Petrides \& Nodine, 2003). According to Metcalfe (2006) knowledge management is renowned as a method for increasing institutional innovation. According to O'Dell \& Grayson, (1998) knowledge management is a strategy used as right knowledge to the right people at the right time and helping people to share information into action to improve organizational performance. Knowledge management applied to Higher Education Institutions (HEIs) can bring about improvement in processes, such as the research process, curriculum development process, student and alumni services, administrative services, and strategic planning (Kidwell, Vander Linde, \& Johnson, 2000). According to Brewer and Brewer (2010) active and dynamic knowledge management practices strategies can help stakeholders of universities for improving organizational and educational achievements.

Knowledge management initiatives as a tool aids in driving innovative processes and maintaining competitiveness within business organizations (Bhatt, 2001; Carneiro, 2000). According to Yeh (2011), knowledge management can be supported by educational authorities and in return knowledge management supports teaching and learning for improving universities. Ramakrishnan and Yasin (2012) articulated that knowledge management system could enhance the curriculum, quality of curricula and its programs. Knowledge management can create the way of competition for Global knowledge economy era. According to Stein (2017) when European public universities faced the crisis of losing students 
in the global field of education competition with American universities have applied knowledge Management Strategy effectively like UK based Southampton Solent University. It is inferred from that knowledge management has potential for competitive advantages.

According to Whyte, Ewenstein, Hales\& Tidd (2008) knowledge management strategy may be achieved through staff's ability to exchange knowledge in universities, flexible mechanisms, infrastructures to facilitate the flow of knowledge and legislation and information for implementation of knowledge management practices. According to (Aurelie Bechina Arntzen, Worasinchai \& Ribière, 2009)described that innovative Knowledge Management practices approaches in higher education of Bangkok University and recommended a generic Knowledge framework. According to Omona et al. (2010) universities need to have appropriate KM framework to effectively manage their knowledge asset. Mehralizade \& Abdi.(2009) investigated the practices of KM in Iranian University and institutional research unit and function supported the KM. The research findings showed that KM strategies, policies and programs cannot smoothly function without institutional research unit and primary coordination point.

Cranfield (2011) emphasized and investigated that what would be the motive of spending of knowledge management budgets. The author further explained the decentralization of power for knowledge management budgets. Tippins (2003) highlighted common budget difficulties to implement knowledge management practices. Budget deficits have negative impact on KM activities in HEIs including increased workload for teachers, decrease in knowledge dissemination through publication and longer processes of problem-solving activities. Geiger (2015) expressed that HEIs of United States have been affected by reductions in budget. There is not enough literature available for studies in Pakistan on impact of Budget on Knowledge management practices. Eram and Arshad (2005) developed knowledge management model for public universities of Pakistan. According to Shah and Mahmood (2015) knowledge management is receiving importance in geo-political circumstances of Pakistan. Knowledge management practices are not getting much attention in Pakistan as well as in developing countries where literacy rate is low. Therefore, researcher was attracted to explore the perception $\mathrm{PhD}$ approved supervisors about knowledge management. 


\subsection{Research Design}

\section{Research Methodology} collection.

The study was quantitative in nature. Survey was conducted for data

\subsection{Population \& Sampling}

The population of the study included all (4634) HEC PhDs approved supervisors in universities of Pakistan. Researcher used multi-stage sampling techniques to select the sample of $465 \mathrm{PhDs}$ for study. At first stage universities were selected and after that subject wise PhDs supervisor were selected.

\subsection{Research Instrument}

Questionnaire was used as data collection instrument.

\subsection{Validity \& Reliability}

The content validity of the instrument was carried out through expert's opinion by $\mathrm{PhD}$ faculty in Education. The reliability co-efficient of the questionnaire was .94

\subsection{Data Collection}

465 questionnaires were distributed among $\mathrm{PhD}$ approved supervisor by E-mail, Google form, and personal visits to the target universities of Pakistan. 326 questionnaires were received from respondents.

\section{Data Analysis \& Results}

Collected data were analyzed through descriptive analysis i.e. percentage by using SPSS. Details are as follows:

Table 1

Knowledge Management Practices: Specific definition for Knowledge Management

\begin{tabular}{lll}
\hline Responses Category & Frequency & Percent \\
\hline Yes & 88 & 27.0 \\
No & 121 & 37.0
\end{tabular}

\begin{tabular}{lll} 
No & 121 & 37.0 \\
Do not know & 117 & 36.0 \\
\hline Total & 326 & 100.0
\end{tabular}

Table 1 illustrates the knowledge management perception in Pakistani universities. There were three categorical choices for answer to obtain the perception of $\mathrm{PhD}$ supervisors. Only $27 \%$ supervisors responded that they have specific definition for knowledge management in their respective universities. There were $37 \%$ perception existed in universities that they have no proper 
definition of $\mathrm{KM}$ and $36 \%$ of the respondents respond that they have no knowledge about KM definition.

Table 2

Availability of strategies and implementation plan for knowledge management practices in universities

\begin{tabular}{lll}
\hline Responses category & Frequency & Percent \\
\hline Yes & 65 & 20.0 \\
No & 104 & 32.0 \\
In the Development Stages & 50 & 15.0 \\
Do Not Know & 107 & 33.0 \\
\hline Total & 326 & 100.0
\end{tabular}

Table 2 described the perceptions about availability of strategies and implementation plan for KM in Pakistani universities. The four options were presented to choose one of them. Only $20 \%$ respondents stated that there are strategies and implementation plan for knowledge management practices in universities. A total of $32 \%$ respondents stated that no strategies and implementation plan for knowledge management practices existed in universities. A small number (15\%) of Pakistani universities were in the development stages of KM plan. There were also 33\% respondents who have no knowledge about such type of plan and strategies for implementation KM practices.

Table 3

Availability of plan for knowledge management practices in universities' departments

\begin{tabular}{lll}
\hline Responses category & Frequency & Percent \\
\hline Yes & 69 & 21.0 \\
No & 139 & 43.0 \\
Do Not Know & 118 & 36.0 \\
\hline Total & 326 & 100.0 \\
\hline
\end{tabular}

Table 3 has three options to obtain perceptions of supervisors about plan of knowledge management in universities department. The only $21 \%$ respondents said that they have plan of KM in universities departments. A total of $43 \%$ of the respondents stated that they have no plan for knowledge management practices in Pakistani universities. On the other hand, $36 \%$ of the respondents opined that they have no knowledge management practices and are unaware about plan of $\mathrm{KM}$ in universities. 
Table 4

Availability of primary coordination point for Knowledge Management practices

\begin{tabular}{lll}
\hline Responses category & Frequency & Percent \\
\hline Yes & 51 & 15.0 \\
No & 157 & 49.0 \\
Do not know & 118 & 36.0 \\
\hline Total & 326 & 100.0
\end{tabular}

Table 4 illustrates the situation of primary coordination point for KM practices in universities of Pakistan. Only $15 \%$ of the respondents opined that they have knowledge about coordination point for KM. A total of $48 \%$ of respondents have no knowledge about KM practices point for coordination and 36\% respondents have no awareness about such type of coordination point for KM.

Table 5

Availability of Knowledge Management framework in universities

\begin{tabular}{lll}
\hline Responses category & Frequency & Percent \\
\hline Yes & 73 & 22.0 \\
No & 129 & 40.0 \\
Do not know & 124 & 38.0 \\
\hline Total & 326 & 100.0 \\
\hline
\end{tabular}

Table 5 illustrates about knowledge management framework. Only $22 \%$ of the respondents stated that they have framework for knowledge management practices in universities. On the other hand, $40 \%$ of the respondents viewed that they have no KM framework and $38 \%$ of the respondents were unaware about such type of framework for KM implementation.

Table 6

Availability of Knowledge Management unit in universities

\begin{tabular}{lll}
\hline Responses category & Frequency & Percent \\
\hline Yes & 60 & 18.0 \\
No & 149 & 46.0 \\
Do not know & 117 & 36.0 \\
\hline Total & 326 & 100.0
\end{tabular}

Table 6 describes availability of KM unit in Pakistani universities. Only 18\% $\mathrm{PhD}$ supervisors responded that they have unit for knowledge management practices in Pakistani universities while $46 \%$ of responses showed non- 
availability of knowledge management unit and 36\% respondents showed that they have no knowledge about unit of KM.

Table 7

Availability of dedicated budgets for Knowledge Management in universities

\begin{tabular}{lll}
\hline Responses Category & Frequency & Percent \\
\hline Yes & 56 & 17.0 \\
No & 113 & 34.0 \\
Do Not Know & 157 & 48.0 \\
\hline Total & 326 & 100.0
\end{tabular}

Table 7 results showed that only $17 \%$ were of the view that they have specific knowledge management budgets in universities while $34 \%$ of the respondents said that they have no definite budgets for KM practices. There were $48 \%$ respondents unaware about the availability of KM budgets.

\section{Findings}

Based on the data analysis, following were findings of the study:-

1. There was absence of specific definition of knowledge management practices in Pakistani universities. Only small numbers of Pakistani universities have definition of knowledge management practices.

2. Implementation plan of knowledge management and strategies were available in some universities while majority of supervisors do not have knowledge management plan and strategies.

3. It was further found that there were no proper coordination point and unit of knowledge management in universities of Pakistan.

4. Availability of knowledge management framework also does not exist in Pakistani universities.

5. Knowledge management units in universities of Pakistan do not exist.

6. Lack of separate budget for knowledge management in Pakistani universities.

\section{Discussion}

Definition of knowledge management adopted in organization as well as in universities supported by Cranfield (2011) results concluded that there was no proper definition of knowledge management. There were no explicit plans of knowledge management as revealed by the study results. The results of Dhamdhere (2015) reflected that there were certain higher educational institutions which have knowledge management plans which is not only for the generation of knowledge. Similarly, the results of the current study were also not in conformity to the results of Chumjit (2013)i.e. knowledge management plans have significant influence on the social development to knowledge-based 
societies. No exact knowledge management practices budget head is allocated in Pakistani universities which negatively influenced the benefits of knowledge management as shown by the study results. These findings were supported by the study of Cranfield (2011) which concluded that most of the institutions have no specified funds for knowledge management. Most of the respondents were unaware about the knowledge management framework, supported by Parikh (2001); Holsapple and Joshi (2002). The results also indicated that knowledge management was never used as tool. These results were not in conformity with the results of Cranfield \& Taylor (2008) which reflected that knowledge management is used in universities of United Kingdom as a tool. Furthermore, Liautaud, Hammond \&_Höhlein (2001) accepted knowledge management as a tool in Higher Education institutions. These conclusions were supported by Cranfield $(2008,2011)$ that there was no sophisticated infrastructure in Higher Education institutions.

\section{Conclusions}

1. The study concluded that there is no specific definition of Knowledge Management and implementation plan available in universities of Pakistan. It was also concluded that some universities don't have a regular plan for knowledge management practices, no coordination point. Also there is no knowledge management framework available in universities of Pakistan.

2. Further, it was concluded that there is no unit available for knowledge management and no specific budget allocated for it. Financial aid always assisted the development program and projects in organization as well as in universities, but the non-availability of dedicated budgets was considered key barrier for implementation of KM.

\section{Recommendations}

1. Pakistani universities may be provided with definitions of Knowledge Management.

2. Knowledge Management plan may also be included in Education Policy.

3. There may be a specific unit for knowledge management in universities.

4. Separate budget for knowledge management practices may be provided.

5. For awareness purpose seminars, conferences, and workshops are the awful need to realize the importance of knowledge management and its proper usage for the developmental purposes are indispensable for university. 


\section{References}

Aurelie Bechina Arntzen, A., Worasinchai, L., \& Ribière, V. (2009). An insight into knowledge management practices at Bangkok University. Journal of Knowledge Management, 13(2), 127-144.

Bhatt, G. D. (2001). Knowledge management in organizations: examining the interaction between technologies, techniques, and people. Journal of knowledge management, 5(1), 68-75.

Brewer, P. D., \& Brewer, K. L. (2010). Knowledge management, human resource management, and higher education: a theoretical model. Journal of Education for Business, 85(6), 330-335.

Carneiro, A. (2000). How does knowledge management influence innovation and competitiveness? Journal of knowledge management, 4(2), 87-98.

Chumjit, S. (2013). Knowledge management in higher education in Thailand (Ph.D. Dissertation). The University of Texas at Arlington.

Cranfield, D., \& Taylor, J. (2008). Knowledge management and higher education: A UK case study. Electronic Journal of Knowledge Management, 6(2).

Cranfield, D. (2011). Knowledge management and higher education: a UK case study using grounded theory (Doctoral dissertation). University of Southampton.

Davenport, T. H., De Long, D. W., \& Beers, M. C. (1998). Successful knowledge management projects. MIT Sloan Management Review, 39(2), 43.

Dhamdhere, S. (2015). Knowledge Management Practices in Education: Indian Scenario. Elixir International Journal. 80, 30824-30834.

Eram, A., \& Arshad, S. (2005, August). Knowledge management in public sector universities of Pakistan. Paper presented in First International Conference on Information and Communication Technologies, IBAKarachi, Pakistan.

Geiger, R. (2015). Impact of the Financial Crisis on Higher Education in the United States. International Higher Education, (59). doi: 10.6017/ihe.2010.59.8486

Holsapple, C. W., \& Joshi, K. D. (2002). Knowledge management: A threefold framework. The Information Society, 18(1), 47-64. 
Kidwell, J. J., Vander Linde, K., \& Johnson, S. L. (2000). Applying corporate knowledge management practices in higher education. Educause quarterly, 23(4), 28-33.

Liautaud, B., Hammond, M., \& Höhlein, H.(2001). E-business intelligence. Moderne Industrie.

Mehralizade, Y., \& Abdi. M. (2009), Knowledge management system (an experience of tax affair organization), Ahvaz, Shahid Chamran University.

Metcalfe, A. S. (2006). The political economy of knowledge management in higher education. Knowledge management and higher education: A critical analysis, 1-20.

Mikulecky, P., \& Saeed L. (2009). Knowledge management at educational institutions: Case of Pakistan. In Mastorakis, N. E., \& et al (Eds.). Proceedings of the $10^{\text {th }}$ WSEASinternational conference on Mathematics and computers in business and economics. Wisconsin, USA, 2009.

Nawaz, M. N., \& Gomes, A. M. (2014). Review of Knowledge Management in Higher Education Institutions. European Journal of Business and Management, 6(7), 71-79

O'dell, C., \& Grayson, C. J. (1998). If only we knew what we know: Identification and transfer of internal best practices. California management review, 40(3), 154-174.

Omona, W., Van der Weide, T., \& Lubega, J. (2010). Using ICT to enhance knowledge management in higher education: A conceptual framework and research agenda. International Journal of Education and Development using Information and Communication Technology, 6(4), 83.

Parikh, M. (2001). Knowledge management framework for high-tech research and development. Engineering Management Journal, 13(3), 27-34.

Petrides, L., \& Nodine, T. (2003). Knowledge Management in Education: Defining the Landscape. ISKME: Distributed by ERIC Clearinghouse.

Ramakrishnan, K., \& Yasin, N. M. (2012). Knowledge management system and higher education institutions. International Proceedings of Computer Science and Information Technology, 37(1), 67-71. 
Rowley, J. (2000). Is higher education ready for knowledge management? International journal of educational management, 14(7), 325-333.

Serenko, A. (2013). Meta-analysis of scientometric research of knowledge management: discovering the identity of the discipline. Journal of Knowledge Management, 17(5), 773-812. doi: 10.1108/jkm-05-20130166

Shah, S. R., \& Mahmood, K. (2015). Research on knowledge management of Pakistan: A literature review. Library Philosophy and Practice (ejournal) 1346.

Sohail, M. S., \& Daud, S. (2009). Knowledge sharing in higher education institutions: Perspectives from Malaysia. Vine, 39(2), 125-142.

Stein, S. (2017). Internationalization for an uncertain future: Tensions, paradoxes, and possibilities. The Review of Higher Education, 41(1), 332.

Tippins, M. J. (2003). Implementing knowledge management in academia: teaching the teachers. International Journal of Educational Management, 17(7), 339-345.

Whyte, J., Ewenstein, B., Hales, M., \& Tidd, J. (2008). Visualizing knowledge in project-based work. Long Range Planning, 41(1), 74-92.

Yeh, Y. M. C. (2011). The Implementation of Knowledge Management System in Taiwans Higher Education. Journal of College Teaching \& Learning (TLC), 2(9). 